\title{
Short food supply chain: characteristics of a family farm
}

\author{
Luane da Conceição Aguiar ${ }^{1}$ Mauro Eduardo DelGrossi' ${ }^{1}$ Karim Marini Thomé ${ }^{*}$ G
}

\begin{abstract}
'Programa de Pós-graduação em Agronegócios (PROPAGA), Universidade de Brasília (UnB), 70910-900, Brasília, DF, Brasil. E-mail: thome.karim@gmail. com. "Corresponding author.
\end{abstract}

\begin{abstract}
Short Food Supply Chains (SFSCs) provide a dependable substitute for conventional supply chains, as their food reflects the characteristics of "local", "natural", "healthy" and "reliable". For the family farmer, the short chains constitute anexcellent way of diversifying their produce, gaining higher added value and thus warranting steadier revenues. This paper thus aims to discern the distinguishing features that the short chains offer, in general, to the family farm. To accomplish this, a literature review was performed to study the works done and approaches conducted on the short chains in the academy, in terms of family farm, and identify their specifications. Positive characteristics related to family farmers were recognizable in comparison with short chains. This article emphasized the significance and need for future research, as well as the necessity for a more extensive exploration of the subject of short chains, focusing attention on this sector, and pinpointing the determinants to be developed in the market.

Key words: short chains, short circuits, food chains, family farm.
\end{abstract}

\section{Short food supply chain: características na agricultura familiar}

RESUMO: As Short Food Supply Chains (SFSCs) surgem como alternativa às cadeias convencionais de suprimentos e associam seus alimentos aos conceitos de local, natural, saudável e confiável. No que se refere ao agricultor familiar, as cadeias curtas representam uma oportunidade atrativa para diversificação da produção, captura de maior valor agregado e garantia de rendas mais estáveis. Assim, o objetivo do presente artigo é identificar as características das cadeias curtas atribuídas à agricultura familiar em geral. Para tanto, procedeu-se a uma revisão de literatura com o objetivo de conhecer os estudos e abordagens realizadas sobre as cadeias curtas na academia, em especifico da agricultura familiar, para então, identificar suas características. Foi possível identificar características positivas associadas ao agricultor familiar frente às cadeias curtas. Este artigo ressalta a importância de que pesquisas futuras sejam realizadas com um maior aprofundamento do estudo das cadeias curtas com foco direto neste segmento, identificando fatores determinantes para o seu desenvolvimento nos mercados. Palavras-chave: cadeias curtas, circuitos curtos, cadeias alimentares.

\section{INTRODUCTION}

The agri-food crises precipitated in the aftermath of World War II had arisen from precarious food safety control. Many epidemics had been triggered, like salmonella and dioxin contaminations, besides others (PIVOTO et al., 2016). Therefore, as a response, studies like these on alternative chains were conducted. Such epidemics kindled consumer interest and greater appreciation for food sources, characteristics and the way that the production, transportation and commercialization have impacted it.

In light of this, so-called "alternative food chains" or "networks" were developed which have generated great interest, over recent years. Therefore, several studies were begun in rural settings, because of a new food policy which focused on satisfying the areas neglected by the conventional government regulations, as well as due to the burgeoning public concern regarding the origin and manipulation of food (MARSDEN, et al., 2000).

MATTE et al., (2016) drew attention to the reflective contributions available in the international literature, which have highlighted the explorative work done and the current connections observed between the alternative and conventional systems, pinpointing the developmental trajectories and the outcomes of the localization motivations.

Such initiatives have arisen in response to the growing oligopolization of the agri-food system. Some of these factors have contributed to the intensification of monopolistic power of the bigger agro-industries, and large-scale producers and retailers, in an attempt to control a large percentage of links in food chains This, 
in turn, has resulted in a disconnect betweenagriculture, food and consumers (ILBERY \& MAYE, 2005).

Thus, the initiation of new food chains in the globalized agricultural economies must be considered in the light of a progression of fundamental reconstructs in the various links present in the agri-food chains (RENTING et al., 2003). Certain categories of the agroindustrial production process, like consumer behavior, land use and labor, in particular, revealed significant alterations (DUARTE \& THOMÉ, 2015).

While identifying the possibilities that the short chains provided, it was crucial to note the theoretical characteristics of these chains highlighted in the literature and their impacts. To accomplish this, a bibliographic review on the short chains was conducted, to pinpoint the theoretical elements or the features of such chains in association with family farm.

\section{MATERIALS AND METHODS}

To fulfill the reason for this article, which involves discerning the theoretical elements or the traits of these chains related to family farm, the literature review technique was adopted.The two methods of literature review included a full evaluation of the literature on a mature topic, which covers an accumulated set of research available for analysis; as well as a review of the emerging theme to identify the probable theoretical foundations (WEBSTER \& WATSON, 2002).

The theme explored in this paper demonstrated that the proposal put forward resonates with the second form of literature review. Literature review attempts to raise the awareness regarding the present literature related to a specific topic and to build the basis for another objective and inspire further research in the area, in future (CRONIN, et al., 2008). Thus, this technique was justifiably selected for its potential to build a solid foundation, further our knowledge, as well as to discover areas that necessitate specific research (WEBSTER \& WATSON, 2002).

The agri-food system encountered crises which have, in turn, triggered the formation of socalled alternative food chains which have opened up debates for new chains in local development, and which incorporate the technical-productive, economic and environmental variables, as well as the social, ethical and cultural values (DAROLT et al., 2016).

While endorsing this view, it was observed that the origin and development of the alternative chains arises as a result of the crises experienced by the conventional model of production and consumption as seen in the traditional chains (DUARTE \& THOMÉ, 2015). From the perspective of this crisis, the appearance of such initiatives is closely linked to the truth that the consumers are growing more keenly interested in understanding the food sources and the processes they undergo, implying that the reconnection with the food source is not always seen within chains (FERRARI, 2011).

In order to achieve this goal, we defined alternative food networks as a group of initiatives with the intention of creating an economic counterpoint to the traditional agri-food system, which includes the adoption of local initiatives, minimal utilization of external inputs in a rural property, smaller production scale, and a focus on quality above productivity (GOODMAN et al., 2012).

MORUZZI MARQUES (2014) proposed that; although, the model of industrial agriculture and mass consumption continue to be dominant, it is possible to state that the alternative models focused on social and ecological sustainability are rapidly developing, and reaching several bigger countries.

In light of this expansion, alternative chains are being seen to emerge from the principles of autonomy, solidarity, food security, social justice, respect for local culture and tradition, as well as the renewed connection between the producers and consumers, evident in the short circuits (DAROLT, et al., 2013).

In this context, the short chains appear to be a reliable alternative to the long chains, which arise from associations with the "local" and "natural", thus exposing the concept of healthy food (SONNINO, MARSDEN, 2006). This comes from the rapidly growing attention over the past few decades, being drawn to the food quality and; therefore, to the widening search for short chains (MARSDEN, et al., 2000).

\section{Concept and types of short chains}

SCARABELOT \& SCHNEIDER

(2012) proposed that short productive chains are commercialization systems of agricultural produce whose objective is more proximity between the producers and consumers, fostering a closer connection between these players, through interactivity in the mutual building up of a relationship of trust.

Short Supply Chains, popularly termed Short Food Supply Chains (SFSCs), are alternative food systems which include several types of distribution, characterized by a few (or no) intermediates between the consumers and producers, or minimal geographical distances separating them from each other (DEVERRE \& LAMINE, 2010).

Thus, a short food supply chain is evident when only very few intermediaries are present between the consumer and the producer or when the geographical distance separating the two is minimal (PARKER, 
2005). Short chains earn this name because of the short distances present between the producers and consumers, in comparison to that of the traditional supply chains, thus minimizing the environmental impacts caused by product transportation (RENTING, et al., 2003).

CHAFFOTTE \& CHIFFOLEAU (2007) more clearly defined short agri-food circuits as the ones that encourage closeness between the producers and consumers, denoting them as distribution circuits that include one mediator at most, between the producer and consumer. Finally, a short circuit can be defined in terms of its geographical proximity, social relations, present link between the producer and consumer, local development and embeddedness of food (Marechal, 2008apud Darolt, 2013).

GALLI \& BRUNORI (2013) explained "short" as the approximation between the producers and consumers, with the fewest number of intermediaries being included in the chain. However, SFSCsare not automatically linked to the reduced physical distances; although, this type of definition also exists.

Apart from this, it is noteworthy that utilizing this term "short" as a common denominator to define such an agro-food chain has gained popularity because of the use of non-specific terms for new or alternative chains (RENTING, et al. (2003)). Although, the SFSCs are accepted, it is essential to know that theyare not merely related to the number of times a product is manipulated or to the geographic distance from where they are transported.

In light of the range of concepts, definitions and, chiefly, the grounds for the regional and cultural diversity in the food systems, no universal definition is available for the ideal physical distance of the short chains (GALLI \& BRUNORI, 2013). Although, certain manuals indicated the maximum distance, in general it is clear that the short chains are associated with fewer numbers of intermediaries present between the producer and consumer.

Knowledge in terms of the views, type and traits of the short chains assumes great significance, as it facilitates a clearer analysis and characterization of these chains, permitting them to know the consumers and emphasize the quality of the final products, highlighting their characteristics of origin and production. Marketing strategies can be thus traced from the distinctions thus identified.

Acknowledging the significance, MARSDEN et al. (2000) identified three types of short production chains: (i) Face-to-face chain which embraces the agricultural products stores, farmers markets and roadside sales, which occur when the consumer directly acquires the produce from the producer or processor. In such an instance, the authenticity, confidence and knowledge about the producer arise via personal interaction, that is, through the direct contact between the producer and consumer; (ii) Spatial proximity chain - items are produced and marketed in specific places and consumers clearly know the local nature of the product at the retail site; other examples of this chain of spatial proximity include products sold at typical festivals and on tourist routes, like the regional brands, consumer cooperatives, fairs, etc.; (iii) Spatially Extended chain - this chain is observed when the value and data on the product in the production sites are conveyed to consumers who reside far from the regions in which they are produced. While such proximity may not be spatial in nature, a clear example of a short-lived extended chain can be observed in the services of traceability, seals of origin, and regional identities that are greatly utilized.

\section{Short chains: importance and benefits}

It was CHIFFOLEAU \& PREVOST (2012)

who proposed that the short circuits can be distinguished as social changes for durable food in the territories, which originate, in the light of the debate on the social and solidarity economy, as a suitable substitute for the state disengagement, neoliberal politics of privatizations and collapse of a market economy that fails to meet population's needs.

In a context identical to this, alternative food networks are a consequence of the current concerns regarding the degree of food security, obesity, and negative social and / or environmental externalities arising from the traditional chains (SONNINNO \& MARSDEN, 2006).

Thusit became clear, that food chains are at times distinguished by their connection with durable and principally healthy food. Short chains also very closely support the concepts of environmental and social preservation, as an appraisal of the negative externalities induced by the traditional chains, according to Harvard, McMeekin and Warde (2004).

Short chains offer the farmers an attractive means of diversifying their production, gaining greater added value and ensuring more stable incomes (ECLAC / FAO / IICA, 2015). From this perspective, the short chains are generally regarded as being great contributors to society.

According to BAVA (2012), another way of perceiving it, is that the conventional chains eliminate, from the sites of their location, the capital from the production and natural resources, utilizing local labor to a minimum and ignoring the factors intrinsic to the Ambiental degradation. Thus, the short chains reveal 
reducedexpenses and lower negative impacts upon the environment, in addition to supporting the regional and local development, and contributing towards the consumers' food quality.

It highlights the claim that short chains are beneficial for the social and economic reproduction of the family farmers, lending support to the views held by MARSDEN et al.(2000). They stated that short agro-food chains play a pivotal role in the new developmental patterns.

Short chains also facilitate producers to gain more value from the food chain, implying that, short chains include social, spatial and economic dimensions, spatial being one, by decreasing the distance that food has to be moved from the sites of production to those of consumption; social being another, by encouraging faceto-face contact between the producers and consumers, building trust and community integration within the chain; besides, local markets are created for production, enabling the primary producers to acquire greater value from the food chain (HARVEYet al., 2004).

\section{Characteristics of short chains in family property}

Family work is one of the strongest supportive pillars for the small-scale properties, which bears a heavy load and must utilize other avenues of knowledge, in order to minimize the costs and increase the product value (DAROLT, et al., 2013). The short chains raise the farmer's autonomy in terms of management, planning and marketing when compared to the long chains.

WILKINSON (2002) showed that smallholder markets are constructed in the rural areas by extending the family relationships with the consumers and the different types of marketing channels. The author terms them "proximity markets", which enjoy frequent transactions, and strong trust relationships between the consumers and agri-food producers, besides interpersonal knowledge.

Therefore, it became evident that those producers who supported the short chains experienced a higher degree of autonomy. Although, this trait was observed in the farmers, it was clear that autonomy did not induce them to market in isolation. From this perspective, autonomy does not include a sense of isolation because it is rooted in the exchange (either formal or informal) between the producers and their contact network, in the contexts of production, processing and marketing (LAMINE, 2012).

DAROLT (2012) understood that the productive units in short chains have greater diversification, operating simultaneously and using a wide selection of vegetable products (olives and fruit) and animal products (eggs, milk and dairy products, sausages and honey). From the perspective of this diversification, it emerges that these productive establishments gravitate towards pluriactivity, with investments in agrotourism, gastronomy, leisure, housing and instructional activities (DAROLT, 2012).

Thus, supported by the assistance of the local circuits, a movement is observed around organic / agroecological production, besides others. MURDOCH (2000) proposed that it requires effort to construct and consolidate alternative markets like the short chains from family farming,

DAROLT et al. (2013) recognized the main marketing channels: viz., direct sale by the family farmer to the consumer can occur on the property site, via basket delivery to the homes, producer fairs and road borders. They also identified methods by which direct and indirect sales can be associated (government programs, fairs and restaurants), or only via indirect means (specialty stores, consumer cooperatives and virtual stores). Most producers utilize the direct sales method to market their produce, followed by indirect sales. The authors claim that when they use the direct sales channels, apart from the producers, they enjoy greater autonomy in their produce and commercialization. These chains generate further benefits including raising producer remuneration, getting fairer prices for the consumer, utilizing the local produce, as well as creating employment and dynamism of the local economy.

Thus, it becomes clear that one of the main features of the short chains is their capacity to "resocialize" or "re-spatialize" a particular food, permitting the consumer to make value judgments drawn from his own knowledge or experience (RENTING et al., 2003).

While employing this identical approach, short circuits, even if included within the long circuits, may support the new social relations prevailing between the producers and consumers, thus ensuring resocialization or food re-spatialization(SONNINO \& MARSDEN, 2006). Some examples linked with the characteristics of the main short circuits of commercialization are given in table 1 .

The short chains, seen as fairs, indicate a type of marketing that reveals proximity between the producers and consumers, in terms of spatial difference, as well as a kind of direct connection which involves interactivity. It also encourages trust relations to be built between the consumer and producer, in which the interactions of the exchange market are more personal and better rooted (SCARABELOT \& SCHNEIDER, 2012). Thus, the short chains in family farmare clearly characterized by the concepts of 
Table 1 - Type of sale, definition and traits of the chief short commercialization circuits for the ecological products, in Brazil.

\begin{tabular}{|c|c|c|}
\hline Sale & Kind & Definition \\
\hline Direct Selling & Sale on the property & $\begin{array}{l}\text { Sale at the production site, directly to the final consumer, without } \\
\text { intermediaries. }\end{array}$ \\
\hline Direct Selling & Home Baskets & $\begin{array}{c}\text { Baskets or bags containing a vast variety of products, delivered on a } \\
\text { daily, weekly or monthly basis. }\end{array}$ \\
\hline Direct Selling & Fairs by the producer & $\begin{array}{l}\text { The fair sells products to the consumer directly from the farmer or from } \\
\text { his marketing network. It is mandatory for the producer or a family } \\
\text { representative to be present. }\end{array}$ \\
\hline Direct Selling & Road border & Tents set up along the highways for direct sale. \\
\hline Direct/Indirect Selling & Fairs, halls and events & $\begin{array}{l}\text { Events organized by the public and private institutions to advertize a } \\
\text { specific product or process. }\end{array}$ \\
\hline Indirect Selling & Specialty Shops & Private enterprises for the sale of organic and ecological products. \\
\hline Indirect Selling & $\begin{array}{l}\text { Consumer cooperatives and } \\
\text { producer association stores set up }\end{array}$ & $\begin{array}{c}\text { Stores selling organic colonial products from a specific area, } \\
\text { functioning as small cooperatives and / or associations of local } \\
\text { producers and consumers. }\end{array}$ \\
\hline
\end{tabular}

Source: Adapted from DAROLT et al., 2013.

rapprochement, direct connection and trust relations between the producer and consumer.

MARSDEN (2004) stated that short supply chains attempt to reinterpret the producer-consumer relationship, giving clear indications regarding the origin of the food product, confirming the view held by DAROLT et al. (2013).

These authors, in their typology, reiterate that it is impressive that in the short chains the involvement in building a closer relationship between the producer and consumer, occurs both in a physical sense, as well as in a set of interconnected values and meanings which actually link them. The proximity thus achieved is one of the outstanding features of the short chains, in which one can continue to find, identify and relate quality and transparency issues. Short circuits, in this sense, have thus been characterized by "quality", "transparency" and "locality" because of the connection between quality and small production, traditional practices, landscapes, nature and local resources.

In their study on three alternative local food networks in South West England, SONINO \& MARSDEN (2006), confirmed that the families investigated followed a mode of production based on the old traditions and this inheritance from the prior generations was strongly rooted in time and space, with a great importance being laid on product quality.

The authors emphasize that the relocation and re-evaluation of food in this area happens because of "retro-innovation". This process involves innovation, in which theelements of a traditional past are associated with the current agricultural practices (SONNINO \&
MARSDEN, 2006). This term also necessitates correct translation and clear communication of some of the aspects of the production practices to the retailers and consumers, by utilizing the right labeling, brand registration, and quality criteria based on the locally reared animals, their producers, and method of processing.

This network of alternative foods reveals the local economies acting as stimuli. They incorporate themselves in their aspects of personal relations, reciprocity and trust, which includes a re-evaluation process of the local production, showcasing a product of specific quality, related to a locality, lifestyle and production.

France, for instance, imposes a rule that in order to be considered a local or short chain, the distance surrounding the property should be within $80 \mathrm{~km}$. The United States Congress, however, in 2008, defined that to be regarded as a local or regionally produced agricultural food product, the total distance permitted for a product to be transported should be within 400 $\mathrm{km}$ from its origin, or else remain within the state of its production. Thus, from the definitions drawn up by France and the United States, various characteristics and parameters are evident when considering a short chain, particularly in terms of the specific territorial area of each country (CRUZ, 2012).

On the other hand, the ECLAC / FAO / IICA (2015) stated that short agri-food chains are not exclusive to only Europe and the United States, as they are also present in Latin America. Thus, it is clearly evident that while the short chains are expanding in Brazil, they continue to remain a rather recent focus of research, without an academic homogenization as yet (DUARTE \& THOMÉ, 2015).

Ciência Rural, v.48, n.5, 2018. 
In light of these facts, it becomes clear that research continues to increase, but a bottleneck is recognizable with respect to the lack of consensus between the theories propounded and the detailed studies that permit the conceptualization of these chains in a homogeneous manner.Thus, researchers must continue to explore and attempt to characterize the short chains in the different regions in Brazil, so that the short chains in this country are succinctly described and identified, as has been done for the countries in Europe.

\section{CONCLUSION}

Short food chains are being widely developed,gaining popularity and reveal great characteristic specificity. As they are an alternative chain type, they can contribute much to the development of family farming. In this context, further studies are warranted,which attempt to highlight the characteristics typical of the short chains, while retaining their focus on family farm, as well as enable the development of this section.

Short chains are normally related to the marketing channels, which includes the direct sale by the family farmer to the consumer. This can take place directly on the site of the property or indirectly through deliveries, as long as the origin of the food product is known. Thus, the features of the short chains are closely linked to the capability of "re-socializing" or "respatializing"a given food.

The short chain characteristics are related to the development and, principally, to the renewed link between the producer and consumer. In terms of development, the short chains are inclined to be a stimulus to the local economies, and increase the autonomy of the producers.

In this context, the distinguishing hallmarks like locality, transparency and quality best describe the products of the short chains and induce a reconnection with the consumer, as the latter grows more aware of the source of these products. Such a reconnection is effected via the proximity observed in the marketing short circuits, meaning, in fairs, direct sales and other sites that enable the consumer to understand from where the products originate.

Other characteristics of the short chains include proximity and connection which indicate "retro-innovation". This involves translating and critically conveying some facets of the productive practices to the retailers and consumers. It creates a strong relation with the tradition of the specific food or the context of its production, being a differential for the commercialization of the product, in light of the present circumstances that the agriculture experiences.
A vital and noticeable difference is that family farming involving the utilization of the short chains concept tilts towards pluriactivity. This facilitates improved development and higher income generated for the producer and, therefore, a superior degree of management autonomy on his property. A genuine relationship between autonomy and commercialization is evident via the short circuits that is, the fairs, local markets, etc., and farmers are likely to acquire greater economic, social and environmental benefits.

Finally, researches conducted on the short chains indicate the advertisement of socioeconomic development, through employment creation and greater development of the local market of food production, inducing the highest level of local development.

This study therefore, contributes towards a greater understanding of the distinct marks of the Short Food Supply Chains, via the bibliographic review method. It has a relatively recent and highly favorable theme, particularly when family farming is the main focus. From current research it is evident that the short agri-food chains are related to the characteristics and the modes of production that ensure food security and support the environment, as well as local and regional development.

One suggestion is that any future research being done should focus more on exploring the short chains, and directly studying family farmand its distinctive and potentials. Besides, one must pay attention to the diverse terms used in the Academy to define Short Food Supply Chain.

\section{ACKNOWLEDGEMENTS}

The authors thank Universidade de Brasília (UNB) and Coordenação de Aperfeiçoamento de Pessoal de Nível Superior (CAPES).

\section{CONFLICT OF INTEREST}

The authors declare no conflict of interest. The founding sponsors had no role in the design of the study; in the collection, analyses, or interpretation of data; in the writing of the manuscript, and in the decision to publish the results.

\section{REFERENCES}

BAVA, S.C. Short circuits of production and consumption. In: FOUNDATION HEINRICH BOLL. A champion seen closely: an analysis of the Brazilian development model. Rio de Janeiro, 2012. Available from: <http://br.boell.org/sites/default/files/downloads/ silvio_bava.pdf>. Accessed: Ago. 4, 2017.

CHAFFOTTE, L.; CHIFFOLEAU, Y. Direct sales and short circuits: evaluations, definitions and typology. The Cahiers de Observatoire CROC, INRA, Montpellier, n. 1, p. 1-8, 2007.Available from:<http://pm22100.net/docs/pdf/04_CC VD/130128_Cahier_de_1_Obs1-INTERNET.pdf $>$.Accessed: Mai. 30, $20 \overline{1}$. 
CHIFFOLEAU, Y.; PREVOST, B. Peasant farming, short circuits, suburban territories: short circuits, social innovations for sustainable food in the territories. Norois, 224, p. 7-20, 2012. Available from: <http://journals.openedition.org/norois/4245>. Accessed: mai. 20, 2017. doi: 10.4000/norois.4245.

CRONIN, P., et al. Undertaking a literature review: a stepby-step approach. British Journal of Nursing, c. 17, n. 1, p. 38-43, 2008. Available from: <https:/www.magonlinelibrary. com/doi/abs/10.12968/bjon.2008.17.1.28059>. doi: 10.12968/ bjon.2008.17.1.28059. Accessed: Ago. 4, 2017.

DAROLT, M. R. Ecological connection: new relationships between farmers and consumers. 1. ed. Londrina: IAPAR, 2012. 162

DAROLT, M.R.,et al., The diversity of ecological food short circuits: lessons from the Brazilian and French case. Experiences in Agroecology, v. 10, n. 2, p. 8-13, 2013. Available from: <http:// www.scielo.br/pdf/asoc/v19n2/1809-4422-asoc-19-02-00001. pdf>. Accessed: Mai. 20, 2017.

DAROLT, M.R.et al. Alternative food networks and new production-consumption relations in France and Brazil. Environment \& Society, v.19, n. 2, 2016. Available from: $<$ http://www.scielo.br/scielo.php?script $=$ sci_arttext\&pid $=\mathrm{S} 1414$ 753X2016000200002\&lang=pt $>$.Accessed: Mai. 20, 2017. doi: 10.1590/1809-4422ASOC121132V1922016.

DEVERRE,C.;LAMINE,C.Les systems agroalimentairesalternatifs: a revue of travauxanglophones in social sciences. Economic Rurale, Agricultures, Alimentations, Territoires, n. 317, p. 57-73, 2010. Available from: <https://www.cairn.info/revue-economie-rurale2010-3-page-57.htm>. Accessed: Mai. 19, 2017.

DUARTE, S. C. L.; THOMÉ, K. M. Short food supply chain: state of the art in the Brazilian academy. Studies Society and Agriculture, v. 23, n. 2, 2015. Available from: <https:// revistaesa.com/V3/ojs-3.1.1/index.php/esa/article/view/575>. Accessed: Mai. 9, 2017.

ECONOMIC COMMISSION FOR LATIN AMERICA AND THE CARIBBEAN (ECLAC); FOOD AND AGRICULTURE ORGANIZATION OF THE UNITED NATIONS (FAO); INTER-AMERICAN INSTITUTE FOR COOPERATION FOR AGRICULTURE (IICA).Short food supply chain as an alternative for promoting family agriculture. Bulletin, 2, 2015. Available from: <http://repositorio.cepal.org/bitstream/handle/11362/37745/ S1500087en.pdf?sequence=1>. Accessed: Mai. 08, 2017.

GALLI, F .; BRUNORI, G. (Eds.). Short supply chains of drivers of sustainable development: evidence document. Document developed in the framework of the FP7 project Foodlinks (GA 265287). Laboratorio di StudiRurali Sismondi, 2013 Available from: <http://www.foodlinkscommunity.net/fileadmin/ documents_organicresearch/foodlinks/CoPs/evidence-documentsfsc-cop.pdf>. Accessed: Jun. 15, 2017.

GOODMAN, D.; et al. Alternative food networks: knowledge, practice, and politics. Abingdon: Routledge, 2012. Available from: $<$ https://www.researchgate.net/publication/236219561 Alternative_Food_Networks_Knowledge_Practice_and_Politics $>$. Accessed: $\bar{M}$ ai. $2 \overline{1}, 2017$.

HARVEY, M.; et al. Qualities of food: alternative empirical and theoretical approaches. Manchester: Manchester University
Press, 2004. Available from: <http://www.jstor.org/stable/j. ctt155j52v>. Accessed: Mai. 20, 2017.

ILBERY, B.; MAYE, D. Food supply chains and sustainability: evidence from specialist food producers in the Scottish/English borders. Land use policy, v. 22, n. 4, p. 331-344, out. 2005. Accessed: Mai. 20, 2017. Available from: <https://www. sciencedirect.com/science/article/pii/S0264837704000614>. doi: 10.1016/j.landusepol.2004.06.002. Accessed: Ago. 4, 2017.

LAMINE, C. Changer de système: uneanalyse des transitions versl'agriculturebiologique à l'echelle des systems agrialimentairesterritoriaux. Terrains etTravaux, v. 20, p. 139-156, 2012. Available from: <https://www.cairn.info/revue-terrains-ettravaux-2012-1-page-139.htm>. Accessed: Mai. 20, 2017.

MARSDEN, T. Theorising food quality: some issues in understanding its competitive production and regulation. In: HARVEY, M.; MCMEEKIN, M.; WARDE, A. (Eds.). Qualities of food. Manchester: Manchester University, 2004. p. 129-153. Available from: <file://C:/Users/User/Documents/341367.pdf>. Accessed: Mai. 10, 2017.

MARSDEN, T. et al. Food Supply Chain Approaches: exploring their role in rural development. Sociologia Ruralis, v. 40, n. 4, p. 424-438, 2000. Available from: <https://onlinelibrary.wiley. com/doi/abs/10.1111/1467-9523.00158>. doi: 10.1111/14679523.00158. Accessed: Mai. 10, 2017.

MATTE, A. et al. Short chain market in family livestock: a process of relocation in the Alto Camaquã Territory in the South of Rio Grande do Sul/ Brazil. Redes, v. 21, n. 3, p. 137-158, 2016. Available from: $<$ https://online.unisc.br/seer/index.php/redes/ article/view/5578>. doi: 10.17058/redes.v21i3.5578. Accessed: Mai. 21, 2017.

MORUZZI MARQUES, P. Eduardo. Criticisms and justifications regarding agricultural alternatives in the state of São Paulo. 2014. Thesis (Free Teaching in Society, Culture and Nature) Luiz de Queiroz College of Agriculture, University of São Paulo, Piracicaba, 2014. Available from: <http://www.teses.usp.br/teses/ disponibleis/livredocencia/11/tde-17092014-084108>. Accessed: Mai. 20, 2017.

MURDOCH, J. Networks: a new paradigm of rural development? Journal of Rural Studies, n. 16, p. 407-419, 2000. Available from:<https://www.sciencedirect.com/science/article/pii/ S074301670000022X $>$. doi: 10.1016/S0743-0167(00)00022-X. Accessed: Mai. 28, 2017.

PARKER, G. Sustainable food: Teikei, co-operatives and food citizenship in Japan and the UK. Working Papers in Real Estate and Planning, 11, 2005. Available from: <https://www. researchgate.net/publication/229012217_Sustainable_food Teikei_Cooperatives_and_food_citizenship_in_Japan_and_the $\mathrm{UK}>$. Accessed: Mai. 20, 2017.

PIVOTO, D. et al. Short chains of food supplies: an opportunity for farmers? Congress of the Brazilian Society of Economics, Administration and Rural Sociology, 54. 2016, Maceió. Available from: <http://icongresso.itarget.com.br/tra/arquivos/ser.6/1/6893. pdf $>$. Accessed: Jun. 15, 2017.

RENTING, H. et al. Understanding alternative food networks: exploring the role of short supply chains in rural development. Environment and Planning A, v. 35, n. 3, p. 393-411, 2003. 
Available from: <http://journals.sagepub.com/doi/pdf/10.1068/ a3510>. doi: 10.1068/a3510. Accessed: Mai. 28, 2017.

SCARABELOT, M.; SCHNEIDER, S. The short agri-food chains and local development: a case study in the municipality of Nova VenezaSC. Do Science, v. 15, n. 20, p. 101-130, 2012. Available from: <http:/ www.ufrgs.br/pgdr/publicacoes/producaotextual/sergio-schneider/ scarabelot-m-schneider-s-as-cadeias-agroalimentares-curtas-edesenvolvimento-local-um-estudo-de-caso-no-municipio-de-novaveneza-sc-faz-ciencia-unioeste-impresso-v-14-p-101-130-2012>. Accessed: Mai. 20, 2017.

SONNINO, R.; MARSDEN, T. Beyond the divide: rethinking relations between alternative and conventional food networks in Europe. Journal of Economic Geography, v. 6, n. 2, p. 181-199, 2006. Available from: $<$ https://academic.oup.com/joeg/article-abstract/6/2/181/909370>. doi: doi.org/10.1093/jeg/lbi006. Accessed: Mai. 20, 2017.

WILKINSON, J. Economic sociology and the functioning of markets: inputs to analyze micro and small agro-industrial enterprises in Brazil. Ensaios FEE, v. 23, n. 2, p. 805-825, 2002. Available from: <https://revistas.fee.tche.br/index.php/ensaios/ article/viewFile/2042/2424>. Accessed: Ago.10, 2017.

WEBSTER, J.WATSON, R. T. Analyzing the past to prepare for the future: writing a literature review. MIS Quarterly, v. 26, n. 2, p. xiii-xxiii, 2002. Available from: <http://www.jstor.org/ stable/4132319>. Accessed: Ago. 10, 2017. 